\title{
TECHNOLOGY AND CHANGES IN SKILL STRUCTURE: EVIDENCE FROM SEVEN OECD COUNTRIES*
}

\author{
Stephen Machin and J ohn Van Reenen
}

\begin{abstract}
This paper compares the changing skill structure of wage bills and employment in the United States with six other OECD countries (Denmark, France, Germany, J apan, Sweden, and the United Kingdom). We investigate whether a directly observed measure of technical change (R\&D intensity) is closely linked to the growth in the importance of more highly skilled workers which has occurred in all countries. Evidence of a significant association between skill upgrading and $R \& D$ intensity is uncovered in all seven countries. These results provide evidence that skill-biased technical change is an international phenomenon that has had a clear effect of increasing the relative demand for skilled workers.
\end{abstract}

\section{INTRODUCTION}

The structure of wages and employment has dramatically shifted in many countries in recent years. There have been big increases in wage inequality in the United States and in the United Kingdom, while other countries (especially those in continental Europe) have had more stable wage structures. At the same time unemployment has risen sharply in several European countries, and almost all countries have seen shifts in employment structure that have adversely affected relatively unskilled workers.

Many commentators believe that much of the change in skill and wage structure in the United States stems from the impact of new technology. Indeed, it has been argued by a large body of economists (e.g., Bound and J ohnson [1992]; Berman, Bound, and Griliches [1994], and J ohnson [1997]) that certain skill-biased technol ogical changes (SBTC) have favored the wage and employment prospects of relatively skilled workers, while simultaneously damaging the wages and employment of the less skilled. Furthermore, if one considers relative employment shifts in the

\footnotetext{
* We would like to thank Thibaut Desjonqueres and Annette Ryan for their exceptional research assistance on this paper (and its earlier versions). We have received a great deal of help with data from many people, notably J ean Bourdon, Richard Dickens, Par Hansson, Mary O'Mahony, Souichi Ohta, George Papaconstantinou, Marcus Rebick, and David Wilkinson. We would like to thank Olivier Blanchard, Lawrence Katz, and two referees for a number of hel pful comments. In addition, Susanne Ackum-Agell, Eric Bartelsman, Eli Berman, Richard Blundell, Richard Dickens, Peter Gottschalk, Zvi Griliches, Daniel Hamermesh, J onathan Haskel, Stephen Nickell, Andrew Oswald, J ohn Schmitt, and participants in numerous seminars have offered useful suggestions. Financial assistance has come from the Leverhulme Trust and the Economic and Social Research Council.

(1) 1998 by the President and Fellows of Harvard College and the Massachusetts Institute of Technology.

TheQuarterlyJ ournal of Economics, November 1998
} 
manufacturing sectors of a number of advanced countries, one sees a pattern similar to that observed in the United States, in that the share of relatively skilled workers in total wage costs and employment appears to have increased (see Berman, Bound, and Machin [1998]). Most of these shifts appear to have occurred within, rather than between industries, leading some commentators to come down in favor of SBTC as the key factor underpinning shifts in relative labor demand.

A difficulty with some of this work is that the effects of technol ogy are inferred as indirect effects associated with particular correlation patterns, or linked to specific components from decompositions, rather than being based upon directly observed comparable measures of technical change across countries. In this paper we consider whether one directly observable indicator of technology, $R \& D$ intensity, is intrinsically associated with the degree of skill upgrading. We adopt an international perspective by looking at the relationship between changes in skill structure and $R \& D$ for comparable data in seven OECD countries: the United States, the United Kingdom (where wage inequality rose even faster in the 1980s than in the United States, al beit from a much lower level), two Continental European countries (France and Germany), two Scandinavian countries (Denmark and Sweden), and J apan. To do so, we construct an original industry-level panel data set from a wide variety of national and international sources. ${ }^{1}$

According to our analysis, there have been shifts in relative labor demand that have favored skilled workers in all seven countries. As in the United States, most of this shift has occurred within, rather than between, industries. Evidence of a significant complementarity of human capital with new technology is uncovered in all seven countries, and this is robust to alternative measures of skill and technology. We do not find that measures of trade, such as the share of imports originating from less devel oped countries, are important in explaining the change in withinindustry skill structures. Our main findings are robust to alternative econometric specifications that allow for the possible endogeneity of technical change and spillover effects.

1. The focus on international comparisons using microeconomic data through time means that our work is closest in spirit to the recent comparison of wage and employment structures in the United States, Canada, and France by Card, Kramarz, and Lemieux [1996]. However, as will be seen below, we employ a somewhat different methodology. 
Overall, our reading of these results is that they provide evidence that skill-biased technical change is an international phenomenon that has had a clear effect of increasing the relative demand for skilled workers. This should not be taken to mean that technology is the only factor in explaining the changing skill structures of the industrialized countries. We cannot deduce the full effect of technology on labor market structure without also closing the model by looking at supply side effects and the nonmanufacturing sector, which is beyond the scope of this paper. Our view is that the results presented here form a necessary, but not sufficient, part of the story that changes in the wage and employment distribution are cl osely tied to technical changes.

The plan of the paper is as follows. The next section describes the construction of the data set and offers some preliminary descriptive statistics. Section III outlines the econometric strategy, and gives a discussion of the basic regression results. Section IV goes on to test the robustness of the results by examining other technol ogy measures, the effects of trade, the potential endogeneity of $R \& D$, and international spillover effects. Some concluding remarks are made in Section $\mathrm{V}$.

\section{DATA Description}

\section{A. Data Construction}

We draw on a number of data sources to construct the industry-level panel data we use in our empirical analysis. The data on value added and investment come from an industry-level panel data set compiled by the OECD known as STAN (Standardized Analytical Database). This contains data which are internationally comparable having been compiled by OECD researchers working with the Central Statistical Offices of each country. The OECD also devel ops complementary databases to STAN. We use their Business Enterprise R\&D (ANBERD) database for $R \& D$ data and the Bilateral Trade Database for international trade information.

STAN/ANBERD is the only data set we know of which contains information on industry-level $R \& D$ expenditures over time across industrialized countries. The industry $R \& D$ measure is comprised of the amount of $R \& D$ conducted by (but not necessarily financed by) the business sector, and this is the key technology measure we rely upon. Of course, we acknowledge 
from the outset that no single proxy for technology is perfect. However, when compared with other existing measures of innovation, R\&D intensity has several advantages for the purposes of our study. First, it is measured in a broadly consistent way over time and across countries. Most industrialized nations use the Frascati Manual definition of $R \& D$, and the OECD statisticians have made considerable efforts to make the measures consistent over time across the countries we consider. ${ }^{2}$ Although a measure of investment in computers or information technology may have some advantages over $R \& D$, these are generally only available for a subset of countries and even then only for a few recent years. Second, R\&D is measured in "dollar terms" (or D-Marks, or pounds, etc). Most measures of innovation such as patents or innovation counts are qualitative in nature. The proportion of workers using a computer does not adjust for the differential amount of resources going into purchasing a computer, for example. Third, it is a direct measure of technology, unlike total factor productivity (TFP) which has the twin disadvantages of being highly endogenous and containing a variety of unknown influences unrelated to technology (such as unmeasured changes in the factor quality mix). Finally, more on the downside, $R \& D$ has the potential drawback that it is only an input (as are the physical investment flows we use to construct the fixed capital stock). Yet, even here, a long line of research has established that $R \& D$ expenditures do a reasonably good job at proxying the outputs of the innovative process. ${ }^{3}$

In terms of data on skills, STAN only has data on total employment by industry and does not disaggregate by skill category. To overcome this, we drew on the United Nations Industrial Statistics Database (UNISD) which includes data on the wage costs and numbers of production and nonproduction workers by industry. Merging the data sets together left us with country-specific time series data on relative wage costs, employment, and R\&D for the same manufacturing industries (defined at about the two-digit level) in each country. From our datamatching procedures (see the Data Appendix) there are actually sixteen industries that make up the entire manufacturing sector

2. For a detailed discussion of the procedures used, see OECD [1997a].

3. For example, Griliches, Hall, and Pakes [1991] have investigated the informativeness of the patent count measure in a dynamic factor model of firm value, $R \& D$, sales, and investment. They found that (with the exception of the pharmaceutical industry) patents provided little additional information on the economic variables above and beyond that contained in $R \& D$ spending. 
in each country. However, when we need to consider the technology measures, we analyze data on fifteen industries, dropping the transport goods sector due to erratic R\&D data. The sample of countries we use is dictated by the availability of data on skill structure and on $R \& D$ intensity. Full information on the matching and cleaning procedures and a listing of industries is given in the Data Appendix.

We have also generalized our empirical work in a number of directions. As one may have doubts about the use of the nonproduction/production worker distinction to proxy skill, we have also constructed education-based measures by aggregating individuallevel cross-sectional data sources to industry-level in France, Germany, J apan, the United Kingdom, and the United States. ${ }^{4}$ Despite problems of consistently defining education groups across countries, we have constructed education-based employment shares at exactly the same industry-level as the combined STAN/ UNISD data through time. In this paper we look only at high education employment shares, which correspond to the proportion of workers in an industry with a college degree.

\section{B. DescriptiveStatistics}

Some descriptive statistics on the key variables for the manufacturing sectors of the seven countries between 1973 and 1989 are reported in Table I. The first point to note is that the nonproduction worker share of the wage bill has risen in all countries and that, in absolute terms, the largest increase has been in the United Kingdom and the United States (with annualized increases of .6 and .5 percentage points per year) and the smallest in Sweden and J apan (both with annualized increases of about .25 percentage points per year). There is a similar pattern for employment shares, but one should notice that the United Kingdom and United States changes are less dramatic here and the size of the change is more in line with that of the other countries, due to the fact that wage differentials between nonproduction and production workers increased very rapidly in those two countries in the 1980s but remained relatively constant elsewhere. In the same way, more highly educated workers have

4. The data sources used are France-EnqueteEmploi; Germany-Mikrozensus; J apan-J apanese Wage Census; the United Kingdom-Labour Force Survey; the United States-Current Population Survey. Note that for Germany and J apan the data on nonproduction shares also come from these sources and not from UNISD. More details are given in the Data Appendix. 
TABLE I

Nonproduction Wage Bill and Employment Shares, Relative Wage Differentials, High Education Employment Shares, and R\&D InTEnsity in Manufacturing

\begin{tabular}{|c|c|c|c|c|c|}
\hline & 1973 & 1977 & 1981 & 1985 & 1989 \\
\hline \multicolumn{6}{|c|}{ Nonproduction wage-bill shares } \\
\hline Denmark & .336 & .338 & .359 & .373 & .402 \\
\hline J apan & $.406(1974)$ & .415 & .428 & .433 & - \\
\hline Sweden & .356 & .385 & .395 & .395 & .396 \\
\hline U.K. & .317 & .333 & .377 & .392 & .414 \\
\hline U.S. & .337 & .351 & .379 & .406 & .414 \\
\hline \multicolumn{6}{|c|}{ Nonproduction employment shares } \\
\hline Denmark & .251 & .270 & .292 & .293 & .318 \\
\hline Germany & - & .292 & .306 & .318 & .327 \\
\hline J apan & $.339(1974)$ & .350 & .364 & .369 & - \\
\hline Sweden & .271 & .288 & .299 & .304 & .303 \\
\hline U. K. & .260 & .278 & .311 & .321 & .325 \\
\hline U.S. & .246 & .261 & .285 & .305 & .303 \\
\hline
\end{tabular}

Nonproduction/production wage differentials

$\begin{array}{lccccc}\text { Denmark } & 1.511 & 1.382 & 1.359 & 1.434 & 1.437 \\ \text { J apan } & 1.331(1974) & 1.314 & 1.310 & 1.309 & - \\ \text { Sweden } & 1.487 & 1.549 & 1.532 & 1.493 & 1.509 \\ \text { U. K. } & 1.316 & 1.292 & 1.340 & 1.366 & 1.470\end{array}$

U.S.

High education employment shares

\begin{tabular}{llllll} 
France & - & .047 & .057 & .081 & .093 \\
Germany & - & .032 & .044 & .054 & .066 \\
J apan & - & .098 & .111 & .129 & .135 \\
U. K. & - & .039 & .054 & .065 & .064 \\
U.S. & - & .088 & .126 & .161 & .167 \\
& \multicolumn{5}{c}{ R\&D intensity (R\&D/value added) } \\
Denmark & .021 & .022 & .027 & .031 & .039 \\
France & .035 & .037 & .046 & .056 & .060 \\
Germany & .032 & .037 & .043 & .052 & .055 \\
J apan & .031 & .036 & .046 & .060 & .070 \\
Sweden & .038 & .050 & .063 & .080 & .081 \\
U. K. & .043 & .046 & .064 & .062 & .060 \\
U.S. & .063 & .062 & .077 & .097 & .087 \\
\hline \hline
\end{tabular}

Nonproduction wage bills, employment, and wages are taken from UNISD or from country-specific micro-data (Germany-Mikrozensus; J apan-Wage Census); R\&D intensity is drawn from ANBERD and STAN; high education shares from micro-data sources in each country (France-Enquete Emploi; GermanySTAN; high education shares from micro-data sources in each country (France-Enquete Emploi; Germany-
Mikrozensus; J apan-Wage Census; U. K.-Labour Force Survey; U. S.-Current Population Survey). For more details see the Data Appendix. High education employment shares are also available for Sweden in two different years (1986 and 1993). Means are.090 in 1986 and .154 in 1993. 
increased their relative employment shares in the countries on which we have data on education. The descriptive statistics in Table I point to considerable shifts in skill structure that have favored more-skilled workers.

The bottom panel of Table I also shows the pattern of $R \& D$ spending across the countries. In $1989 R \& D$ intensity (R\&D divided by value added) was highest in the United States and lowest in Denmark. It is also interesting to note the time series pattern. All countries have increased the proportion of value added given over to R\&D between 1973 and 1989, with the largest increases occurring in J apan and Sweden. More detailed analysis of the increasing $R \& D$ intensities reveals both an increasing importance of high-tech industries and also a general increase in manufacturing $R \& D$ across almost all industries [Van Reenen 1997].

As studied in much more detail in Berman, Bound, and Machin [1998], the bulk of the change in skill proportions is going on within, rather than between, industries. Our disaggregated data on the sixteen industries within manufacturing al so allows a comparison of the within/between changes using education rather than occupation as a definition of skill. Figure I reports the familiar decomposition of aggregate changes in skilled wage-bill and employment shares into within-industry and betweenindustry components. ${ }^{5}$ In all seven countries the vast majority of skill upgrading is happening within industries, and this is true for both the occupational and educational proxies for skill. ${ }^{6}$

Berman, Bound, and Machin [1998] also present empirical evidence that faster skill upgrading is concentrated in similar industries in different countries and argue that this is consistent with the idea that SBTC has had a pervasive effect in shifting relative labor demand in favor of skilled workers across countries.

5. The aggregate change in the skilled proportion over a given time period, $\Delta P$, can be decomposed (for industries $i=1,2, \ldots, N$ ) as

$$
\Delta \mathrm{P}=\sum_{\mathrm{i}} \Delta \mathrm{S}_{\mathrm{i}} \overline{\mathrm{P}}_{\mathrm{i}}+\sum_{\mathrm{i}} \Delta \mathrm{P}_{\mathrm{i}} \overline{\mathrm{S}}_{\mathrm{i}},
$$

where $P_{i}=S K_{i} / L_{i}$ is the proportion of skilled workers in industry $i$ and $S_{i}=L_{i} / L$ is the share of total employment in industry $i$. A bar over a variable denotes a time mean. The first term on the right-hand side of the equation is the change in the aggregate proportion of skilled workers attributable to shifts between industries with different proportions of skilled workers. The final term in the expression is the change in the aggregate proportion of skilled workers attributable to changes in the proportion of skilled workers within industries.

6 . This pattern remains true in nonmanufacturing sectors and also for more disaggregated industry definitions (see Machin and Van Reenen [1997]). 


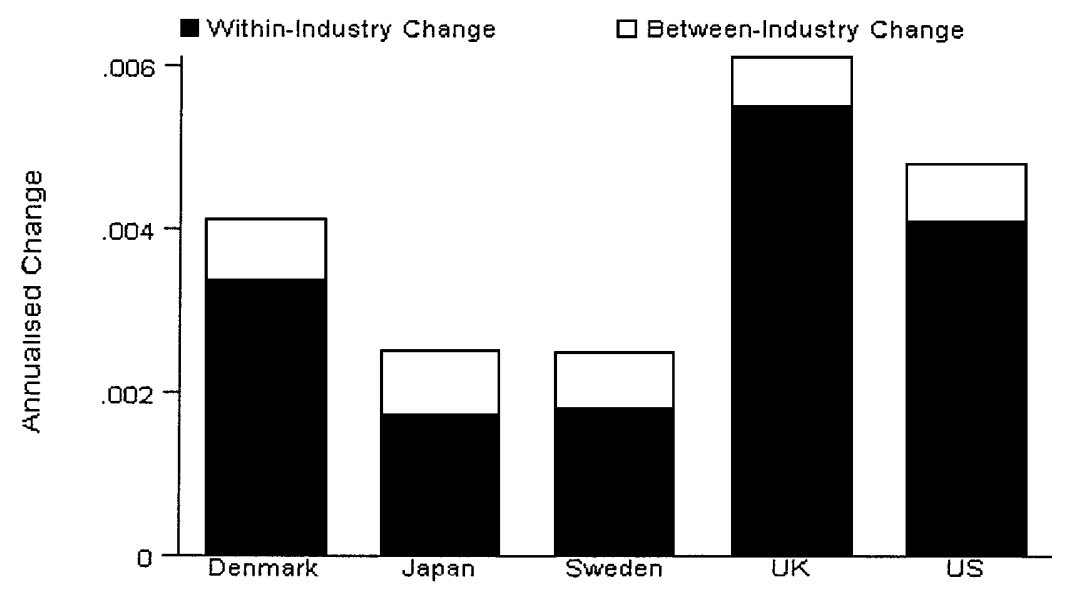

Changes in Non-Production Wage Bill Shares

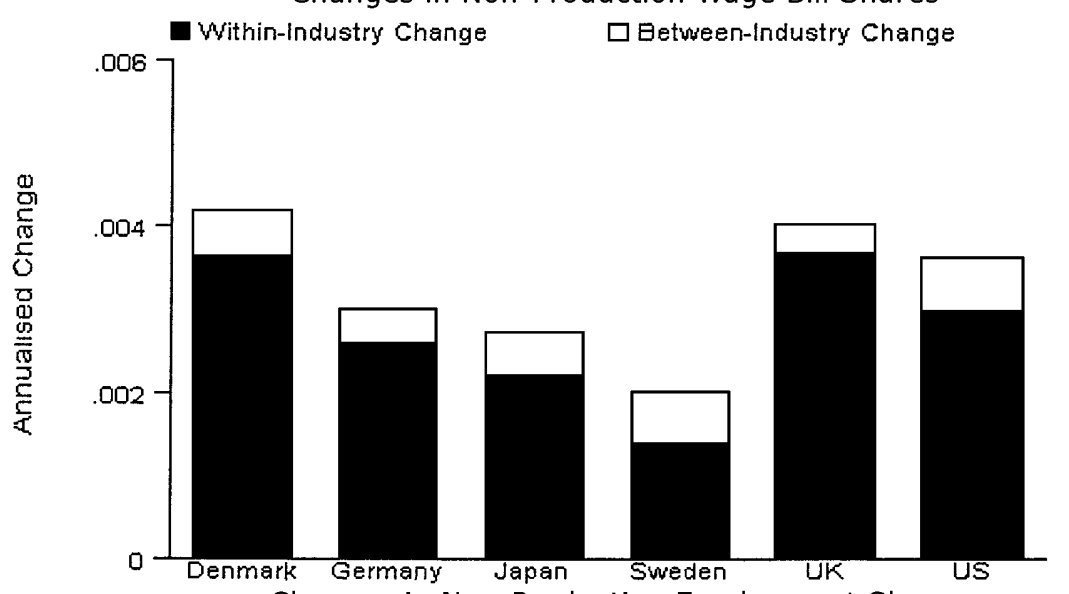

Changes in Non-Production Employment Shares

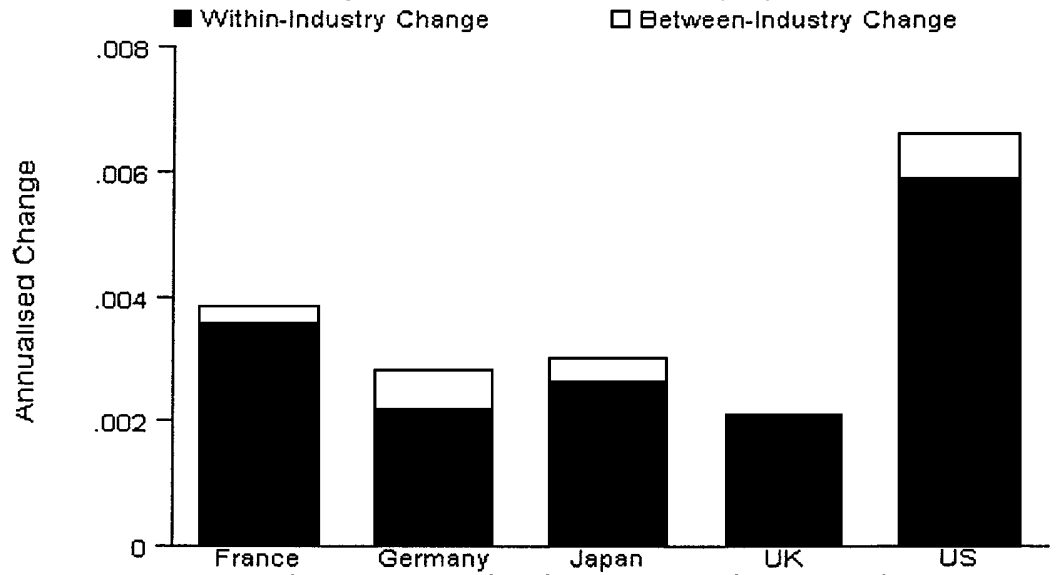

Changes in High Education Employment Share

FIGURE I

Changes in Nonproduction Wage Bill and Employment Shares (1973-1989 except

J apan 1974-1985) and High Education Employment Shares

(1977-1989) - within/between Components of Annualized Changes 
In our data we are able to break down the overall change in the nonproduction or education shares into each of the manufacturing sectors and then rank the industries by their within-industry contribution to the overall change. It is clear by just eyeballing these rankings that, for the most part, the biggest changes are concentrated in the same industries across countries. The industries with the biggest individual contributions are computers and nonelectrical machinery, professional goods (i.e., instruments) and paper, printing, and publishing. The existence of crosscountry correlations of industry skill upgrading is important and suggests that a key empirical strategy should be to isolate what factors are common to the industries in which faster skill upgrading is concentrated. Yet it remains difficult to be fully convinced that these kinds of cross-country industry correlations signify a SBTC shock in the absence of direct measures of technol ogy. ${ }^{7}$

That technical change is clearly a candidate for explaining the observed shifts is indicated by the fact that the same industries tend to be $R \& D$ intensive across countries. This is shown in Table II which reports cross-country correlations in industrial $R \& D$ intensity (only fifteen industries are now considered because, as noted above, we drop the transport goods industry due to worries about the reliability of the R\&D data). All pairwise correlations are positive, large in magnitude, and significantly different from zero. ${ }^{8}$ This clearly mirrors the observation that faster skill upgrading is observed in similar industries in different countries, although the $R \& D$ correlations are clearly stronger than the skill upgrading correlations. ${ }^{9}$ The latter suggests that other factors may also be at play. It is in the spirit of

7. Recent work by Haskel and Slaughter [1998] has also emphasized that technical change may have effects on the between-industry component as well as on within-industry shifts in relative employment.

8. Industries with consistently high $R \& D$ intensities were nonelectrical machinery (including computers), chemicals (including drugs) and electrical, radio, TV, and communications (mean $R \& D$ intensities across all seven countries for these three industries were $.060, .102$, and .134, respectively). On the other hand, consistently low (R\&D/valueadded) was present in the textiles, apparel, and leather, and wood products and furniture industries (mean $R \& D$ intensities were .006 and .003).

9. The skill upgrading correlations in our data are in line with those in Berman, Bound, and Machin [1998] even though our data are more aggregated (they consider 28 industries, as compared with our 15). For example, for the ten possible pairwise comparisons of cross-country correlations in nonproduction wage-bill shares (for Denmark, J apan, Sweden, the United Kingdom, and the United States), all were positive, and five were statistically significant at the 5 percent level. For the 1980-1990 time period, and for a wider range of countries, Berman, Bound, and Machin [1998] report that 12 out of 36 cross-country correlations of changes in nonproduction wage-bill shares were significant. 
TABLE II

Cross-Country Correlations in Industry R\&D InTEnsity (FIfTEen Manufacturing Industries, 1973-1989 Averages, Weighted by Cross-Country Mean Industry Value Added Shares)

\begin{tabular}{lcccccc}
\hline \hline & \multicolumn{5}{c}{ Cross-country correlations of industry (R\&D/Y) } \\
\cline { 2 - 7 } & Denmark & France & Germany & J apan & Sweden & U. K. \\
\hline France & $.68^{*}$ & & & & & \\
& $(.01)$ & & & & & \\
Germany & $.79^{*}$ & $.97^{*}$ & & & & \\
& $(.00)$ & $(.00)$ & & & & \\
J apan & $.66^{*}$ & $.95^{*}$ & $.97^{*}$ & & & \\
& $(.01)$ & $(.00)$ & $(.00)$ & & & \\
Sweden & $.73^{*}$ & $.97^{*}$ & $.97^{*}$ & $.96^{*}$ & & \\
& $(.00)$ & $(.00)$ & $(.00)$ & $(.00)$ & $.98^{*}$ & \\
U. K. & $.73^{*}$ & $.98^{*}$ & $.95^{*}$ & $.92^{*}$ & $.9 *^{*}$ & \\
& $(.00)$ & $(.00)$ & $(.00)$ & $(.00)$ & $(.00)$ & $.93^{*}$ \\
U. S. & $.68^{*}$ & $.90^{*}$ & $.85^{*}$ & $.91^{*}$ & $.90^{*}$ & $.90)$ \\
& $(.01)$ & $(.00)$ & $(.00)$ & $(.00)$ & $(.00)$ & $(.00)$ \\
\hline \hline
\end{tabular}

These are pairwise correlation coefficients based on fifteen manufacturing industries (except for correlations for Denmark which are based on fourteen industries due to missing data on the petroleum industry). They are weighted by the pairwise cross-country mean industry value added share in total value added. p-values testing the null of independence are in parentheses (an asterisk denotes significance at .05 level or better).

these data patterns that we next turn to regression models which essentially try to see whether it is in fact broadly the same industries that have simultaneously experienced skill upgrading and technical change.

\section{Empirical Models of Changes in Skill Structure AND TECHNOLOGY}

\section{A. Econometric Approach}

Beginning from a simple restricted variable translog cost function for industry $i$ in country $j$ in year $t$, say $C\left[\log \left(W^{N P}\right)_{i j t}\right.$, $\left.\log \left(W^{P}\right)_{i j t}, \log \left(K_{i j t}\right), \log \left(Y_{i j t}\right), T E C H_{i j t}\right]$, it is straightforward to derive a nonproduction wage-bill-share equation as

(1) $\operatorname{SHARE}_{i j t}=\varphi_{i j}+\alpha_{j} \log \left(K_{i j t}\right)+\beta_{j} \log \left(Y_{i j t}\right)$

$$
+\gamma_{\mathrm{j}} \mathrm{TECH}_{\mathrm{ijt}}+\delta_{\mathrm{j}} \log \left(\mathrm{W}^{\mathrm{NP}} / \mathrm{W}^{\mathrm{P}}\right)_{\mathrm{ijt}} \text {, }
$$

where SHARE is the nonproduction wage-bill share, $K$ is the tangible capital stock (assumed to be a quasi-fixed factor), $Y$ is 
value added, $\mathrm{W}^{\mathrm{NP}}$ and $\mathrm{W}^{\mathrm{P}}$ are the wage rates of nonproduction and production workers, and TECH is a measure of the stock of technology. ${ }^{10}$ The $\mathrm{j}$ subscript attached to the coefficients allows them to vary across countries (although in practice we estimate separate equations for each country). We time difference equation (1) in order to sweep out the correlated industry-specific fixed effects $\varphi_{i j}$. The stochastic form of the estimating equation (with $\Delta$ being a difference operator and $u$ a random error term) is therefore

$$
\text { (2) } \begin{aligned}
\Delta \operatorname{SHARE}_{\mathrm{ijt}}=\alpha_{\mathrm{j}} \Delta \log \left(\mathrm{K}_{\mathrm{ijt}}\right)+ & \beta_{\mathrm{j}} \Delta \log \left(\mathrm{Y}_{\mathrm{ijt}}\right) \\
& +\gamma_{\mathrm{j}}(\mathrm{R} \& \mathrm{D} / \mathrm{Y})_{\mathrm{ijt}}+\eta_{\mathrm{jt}} \mathrm{D}_{\mathrm{jt}}+\mathrm{u}_{\mathrm{ijt}} .
\end{aligned}
$$

Notice that the relative wage rates have been replaced by country-specific time dummies $\left(D_{j t}\right)$ which will also capture common macroeconomic shocks. The differenced industry-specific relative wage terms could be entered separately in (2), but they are likely to be highly endogenous. In the absence of any convincing instruments, wages are assumed to move in tandem across the economy (levels are captured by the fixed effect). Some specification tests reported below relax this assumption and show the results to be robust to the inclusion or exclusion of the industryspecific relative wage.

More importantly in terms of specification issues, the main variable used to measure the change in the technology stock, $\triangle T E C H$, is $R \& D / Y$, the ratio of the flow of $R \& D$ expenditures to value added. As we have noted above, we think this is a good measure of technological progress and is the main variable we consider in our empirical work. Some results based on alternative technol ogy measures are ther efore al so discussed bel ow.

In terms of the specifications to be estimated, one should also note that, because industrial $R \& D$ intensity tends to be persistent over time, then in terms of timing, the way in which the variableis entered into equation (2) makes little difference to the nature of the results. For most of the analysis below we enter it as the average over the period used in differencing, but we also discuss results using lagged $(R \& D / Y)$ and the initial (1973) value.

Finally, because yearly variations in industrial $R \& D$ intensity tend to be small, one may believe that the estimation of

10. Notice that, in this framework, SHARE is the share of nonproduction worker wages in the overall wage bill, not total costs, as the only variable factors of production are the two labor types (since the capital and technology stocks are assumed quasi-fixed). 
models based on annual industry data is not suitable. As such, the main results that we present specify equation (2) in longer frequency differences (four-year changes). Nevertheless, the results are robust to using shorter or longer changes, and we also report results from annual data. All reported results are based on annualizing the data to ensure comparability across models based on data of different frequencies.

\section{B. Basic Regressions}

Table III reports simple regressions of (annualized) four-year and one-year changes in skilled wage-bill and employment shares on $R \& D$ intensity (and year dummies). F or the four-year models, where we have full data, these models cover four time periods (1973-1977, 1977-1981, 1981-1985, and 1985-1989), and exceptions to this are detailed in the notes to the table. Because the specifications cover the same industries in different time periods, we let the industry-specific errors becorrelated over time (in other words, we allow for random effects in the differenced specifications). Each equation also incorporates a set of year dummies to control for country-specific common time effects.

In all cases, the estimated coefficients on the $R \& D$ variable are positive and are almost al ways statistically significant at the 5 percent level. Only in three cases out of seventeen in the four-year change models (Sweden, changes in nonproduction wage-bill shares; United Kingdom, changes in high education employment shares; United States, changes in high education employment shares) is the estimated coefficient on $R \& D$ intensity not significant at the 5 percent level, and even there the p-values testing the null hypothesis of no association are $.15, .07$, and .07 , respectively. In the one-year change models fourteen of the sixteen of the estimated $R \& D$ coefficients are significantly different from zero (and the two that are not-high education employment shares in the United Kingdom and the U nited States-have p-values of .22 and .07 , respectively). ${ }^{11}$

The regressions therefore paint a very clear picture about the relationship between skill upgrading and $R \& D$ intensity. It is clearly the more R\&D-intensive industries that have seen faster

11. The same pattern of results is al so preserved in longer differenced models. Exactly the same pattern also emerged if lagged $(R \& D / Y)$ was entered $(t-1$ for the one-year changes, $\mathrm{t}-4$ for the four-year changes). Notice also that the one-year models use all the data we have compiled and in some countries this goes up to 1991. As such, the coefficients are not strictly comparable (but restricting to the same time period as the four-year models produced similar results). 
TABLE III

Basic Regressions of Changes in Skill Upgrading on R\&D Intensity-Four-Year Changes (Annualized) and One-Year Changes

\begin{tabular}{|c|c|c|c|c|c|}
\hline & & & $\begin{array}{l}\text { Changes in } \\
\text { nonproduction } \\
\text { wage-bill } \\
\text { share }\end{array}$ & $\begin{array}{l}\text { Changes in } \\
\text { nonproduction } \\
\text { employment } \\
\text { share }\end{array}$ & $\begin{array}{l}\text { Changes in } \\
\text { high education } \\
\text { employment } \\
\text { share }\end{array}$ \\
\hline \multirow[t]{4}{*}{ Denmark } & $\begin{array}{r}\text { Four-year } \\
\text { changes }\end{array}$ & $\begin{array}{l}\text { Coefficient (standard } \\
\text { error) on } R \& D / Y\end{array}$ & $.028(.013)$ & $.031(.012)$ & \\
\hline & & Sample size & 56 & 56 & \\
\hline & $\begin{array}{l}\text { One-year } \\
\text { changes }\end{array}$ & $\begin{array}{l}\text { Coefficient (standard } \\
\text { error) on } R \& D / Y\end{array}$ & $.024(.011)$ & $.021(.009)$ & \\
\hline & & Sample size & 173 & 173 & \\
\hline \multirow[t]{4}{*}{ France } & $\begin{array}{r}\text { Four-year } \\
\text { changes }\end{array}$ & $\begin{array}{l}\text { Coefficient (standard } \\
\text { error) on } R \& D / Y\end{array}$ & & & $.052(.008)$ \\
\hline & & Sample size & & & 42 \\
\hline & $\begin{array}{l}\text { One-year } \\
\text { changes }\end{array}$ & $\begin{array}{l}\text { Coefficient (standard } \\
\text { error) on } R \& D / Y\end{array}$ & & & $.047(.003)$ \\
\hline & & Sample size & & & 196 \\
\hline \multirow[t]{4}{*}{ Germany } & $\begin{array}{r}\text { Four-year } \\
\text { changes }\end{array}$ & $\begin{array}{l}\text { Coefficient (standard } \\
\text { error) on } R \& D / Y\end{array}$ & & $.021(.007)$ & $.026(.007)$ \\
\hline & & Sample size & & 45 & 39 \\
\hline & $\begin{array}{l}\text { One-year } \\
\text { changes }\end{array}$ & $\begin{array}{l}\text { Coefficient (standard } \\
\text { error) on } R \& D / Y\end{array}$ & & $.024(.007)$ & $.022(.007)$ \\
\hline & & Sample size & & 210 & 186 \\
\hline \multirow[t]{4}{*}{ J apan } & $\begin{array}{r}\text { Four-year } \\
\text { changes }\end{array}$ & $\begin{array}{l}\text { Coefficient (standard } \\
\text { error) on } R \& D / Y\end{array}$ & $.050(.016)$ & $.043(.017)$ & $.019(.008)$ \\
\hline & & Sample size & 45 & 45 & 45 \\
\hline & $\begin{array}{l}\text { One-year } \\
\text { changes }\end{array}$ & $\begin{array}{l}\text { Coefficient (standard } \\
\text { error) on } R \& D / Y\end{array}$ & $.037(.015)$ & $.034(.014)$ & $.020(.008)$ \\
\hline & & Sample size & 174 & 174 & 189 \\
\hline \multirow[t]{4}{*}{ Sweden } & $\begin{array}{r}\text { Four-year } \\
\text { changes }\end{array}$ & $\begin{array}{l}\text { Coefficient (standard } \\
\text { error) on } R \& D / Y\end{array}$ & $.013(.009)$ & $.020(.008)$ & $.032(.007)$ \\
\hline & & Sample size & 45 & 45 & 15 \\
\hline & $\begin{array}{l}\text { One-year } \\
\text { changes }\end{array}$ & $\begin{array}{l}\text { Coefficient (standard } \\
\text { error) on } R \& D / Y\end{array}$ & $.036(.011)$ & $.038(.009)$ & \\
\hline & & Sample size & 157 & 157 & \\
\hline \multirow[t]{4}{*}{ U.K. } & $\begin{array}{r}\text { Four-year } \\
\text { changes }\end{array}$ & $\begin{array}{l}\text { Coefficient (standard } \\
\text { error) on } R \& D / Y\end{array}$ & $.024(.009)$ & $.025(.009)$ & $.013(.007)$ \\
\hline & & Sample size & 60 & 60 & 45 \\
\hline & $\begin{array}{l}\text { One-year } \\
\text { changes }\end{array}$ & $\begin{array}{l}\text { Coefficient (standard } \\
\text { error) on } R \& D / Y\end{array}$ & $.026(.009)$ & $.026(.009)$ & $.011(.009)$ \\
\hline & & Sample size & 255 & 255 & 210 \\
\hline \multirow[t]{4}{*}{ U.S. } & $\begin{array}{r}\text { Four-year } \\
\text { changes }\end{array}$ & $\begin{array}{l}\text { Coefficient (standard } \\
\text { error) on } R \& D / Y\end{array}$ & $.024(.007)$ & $.020(.007)$ & $.025(.014)$ \\
\hline & & Sample size & 60 & 60 & 45 \\
\hline & $\begin{array}{l}\text { One-year } \\
\text { changes }\end{array}$ & $\begin{array}{l}\text { Coefficient (standard } \\
\text { error) on } R \& D / Y\end{array}$ & $.021(.007)$ & $.022(.007)$ & $.020(.011)$ \\
\hline & & Sample size & 270 & 270 & 210 \\
\hline
\end{tabular}

Nonproduction shares: four-year changes are based on fifteen industry manufacturing panel data for four time periods (1973-1977, 1977-1981, 1981-1985, 1985-1989) for all countries except Germany (1977-1981, 1981-1985, 1985-1989), J apan (1974-1977, 1977-1981, 1981-1985), and Sweden (1973-1977, 1977-1981, 1981-1985). Full sample sizes are 60 but may be less due to data problems in some industries and years. Education shares: four-year changes are based on fifteen industry manufacturing panel data for three time periods (1977-1981, 1981-1985, 1985-1989) except for Sweden (1986-1993). One-year-change models use data on all availableyears. All four-year changes are annualized, and all regressions include a full set of time dummies. Regressions are dummies. Regressions are weighted by industry size (wage bill share or employment share). Estimation is by $\mathrm{GLS} /$ random effects where the industry errors are allowed to be correlated for industries over time Heteroskedasticity-consistent standard errors are in parentheses. 
increases in nonproduction wage-bill and employment shares and high education shares in the seven countries we study. We view the fact that a significant correlation is obtained for "skill" measures based on nonproduction and education-based shares as very reassuring for interpreting the observed changes as illustrating faster skill upgrading associated with higher industry $R \& D$ intensity in these countries.

\section{Estimates of Extended Cost-ShareE quations}

The results of implementing the more detailed econometric models based on equation (2) are contained in Table IV. The table reports models analyzing changes in nonproduction wage-bill shares and reports four specifications for each country. The first two rows contain coefficient estimates from models based on four-year changes with the first row imposing constant returns to scale (CRS: $\alpha_{j}=-\beta_{j}$ in the context of equation (2)) and the second row relaxing this assumption. The third and fourth rows reports analogous models based on annual year-on-year changes.

Overall, the wage-bill share models in the upper panel of Table IV are very much in line with the skill-biased technological change hypothesis as there is evidence of a positive association between new technology and changes in skilled wage-bill shares in all five countries considered. The coefficient on $R \& D / Y$ is estimated to be positive across all specifications and is significantly different from zero in almost all cases. ${ }^{12}$ We also find a positive correlation between the growth of capital intensity and the skill upgrading in every country except J apan. This is important as it is likely that some of the effect of technol ogy on the labor market occurs through being "embodied" in more recent vintages of capital goods. What is more, the estimated coefficients are robust to specification of equations in four-year changes as compared with looking at annual year-on-year regressions.

12. In terms of equations (1) and (2) it is worth noting that we allow for industry fixed effects in the level of skill intensity but do not allow for fixed effects in the growth rates (i.e., we do not incorporate industry-specific trends in the levels equation). This is because allowing there to be permanent industry effects in the differenced equations is incoherent in the long run. Nevertheless, if we do include them in equation (2), the coefficients on $(R \& D / Y$ ) are (unsurprisingly given the sample sizes) driven to insignificance. This is in line with well-known findings in the literature on productivity and R\&D (e.g., Hall and Mairesse [1995]): most of the variance in $R \& D$ intensity is between rather than within units. Recovering the industry fixed effects and regressing them against $R \& D$ intensity reveals positive and significant correlations, illustrating that more R\&D-intensive industries are those with faster skill upgrading. 
TECHNOLOGY AND CHANGES IN SKILL STRUCTURE 1229

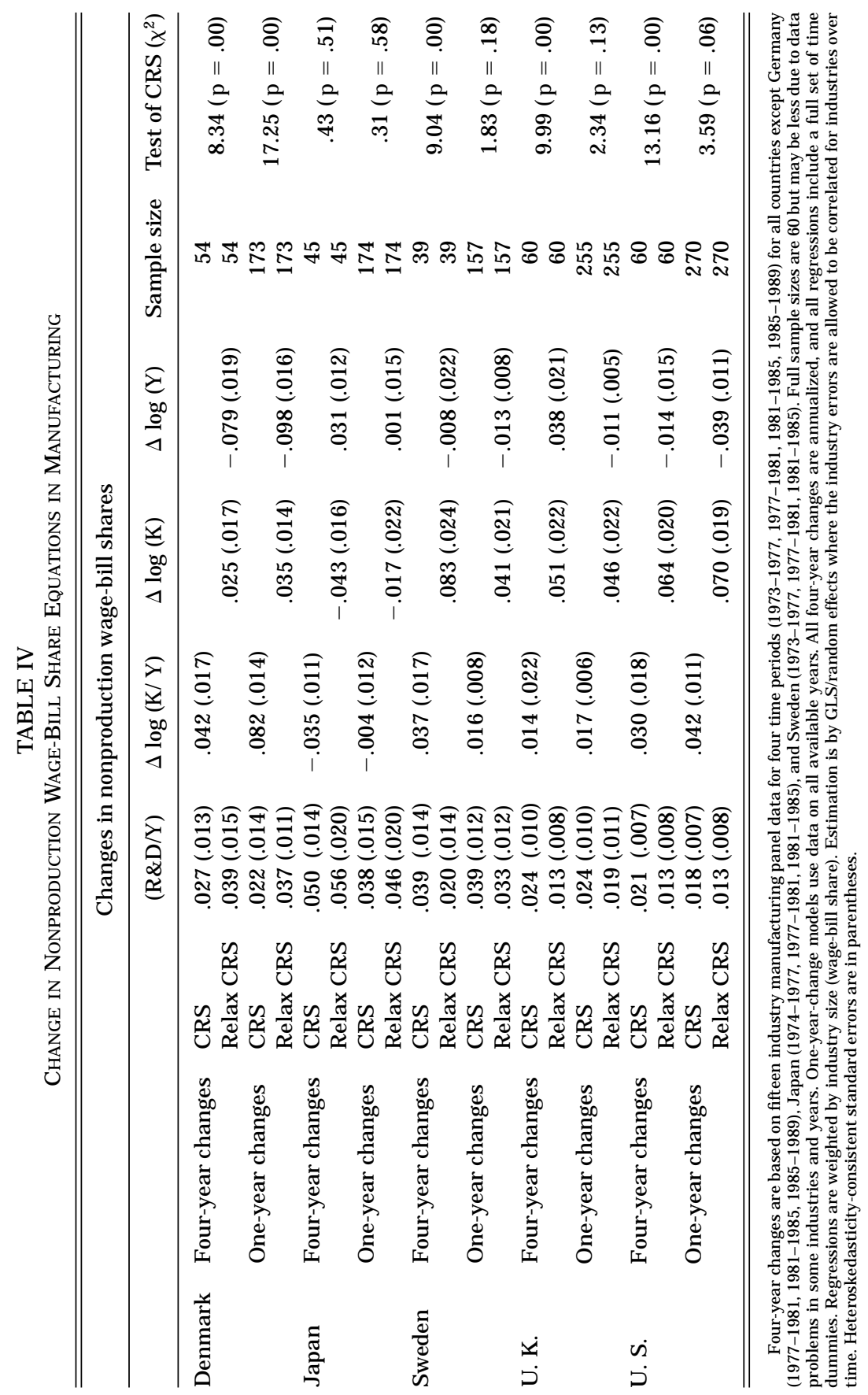


We have also estimated employment share equations that reveal broadly supportive results, with $R \& D$ intensity being positively and significantly associated with faster growth of the proportion of skilled employees. These equations are reported in Appendix 1. One should note that the parameter estimates in the employment-share equations were robust to including relatively industry wage terms-defined as $\left.\log \left(\mathrm{W}^{\mathrm{NP}}\right) / \mathrm{W}^{\mathrm{P}}\right)_{\mathrm{ijt}}$ - where the NP and $\mathrm{P}$ superscripts stand for nonproduction and production, respectively. However, this is where the only notable difference between the four-year and one-year growth models occurred. In the year-on-year regressions the coefficient on the relative wage is fairly precisely estimated and is significantly negative in all countries except J apan. Furthermore, they hint at a stronger (i.e., more negative) wage effect in the United States than elsewhere. This pattern is less clear in the longer differenced models where the wage effects are estimated with much less precision.

Finally, returning to the wage-bill-share equations, when the relative wageterms were included in the wage-bill-share specifications, their coefficients were estimated to be positive, but it should be noted that, since the dependent variable includes wage terms in its definition, the estimated coefficients on the relative wage terms are biased upward. Despitethis, but most important for our focus, the coefficients on the R\&D and physical capital terms were essentially unaffected by the inclusion of the industry-specific relative wage terms. ${ }^{13}$

\section{Cross-Country Differences in theSize of theTechnical ChangeEffect}

To what extent is the effect of R\&D similar across countries? Simply looking at the estimated coefficients in Table IV gives the impression that their magnitude differs, and given that skill upgrading has occurred to a different degree across countries, their ability to explain the observed changes varies across countries. The most pertinent observation here is that the $R \& D$ coefficients are smallest in the United Kingdom and the United

13. For the five countries considered (non-CRS specifications) they were as follows (standard errors are in brackets): four-year changes-Denmark .038 (.015); J apan .056 (.020); Sweden .022 (.008); the United Kingdom .015 (.011); the U nited States .012 (.008); one-year changes-Denmark .035 (.010); J apan .044 (.020); Sweden .032 (.007); the United Kingdom .021 (.012); the United States .013 (.008), 
States, yet skilled wage-bill and employment shares rose fastest in those two countries. ${ }^{14}$

To probe the differences further, we pooled the data and tested restricting the $R \& D$ coefficients to be common across countries. One cannot reject moving from the most general specification (with all variables allowed to have different effects by country) to the restricted model where there is a common $R \& D$ coefficient. In the four-year change wage-bill and employment share models for the five countries with employment and wage data (Denmark, J apan, Sweden, the United Kingdom, and the United States), pooled data models with a common R\&D effect produced coefficients (and associated standard errors) of .021 (.006) in the wage-bill-share equation and .021 (.007) in the employment-share equation. A $\chi^{2}(4)$ test of constancy of the estimated R\&D effect across countries produced a test statistic of 6.96 for wage-bill shares and 7.11 for employment shares (5 percent critical value $=9.49$ ).

A more detailed examination of these results, however, revealed that one can identify some country-specific variations around these average effects. In fact, for both wage bills and employment shares, a model that restricts the United Kingdom and the United States to have equal R\&D effects, Denmark and $J$ apan to have equal effects, and lets Sweden have its own $R \& D$ effect cannot be restricted to the common $R \& D$ coefficient model. In this model the R\&D coefficients are smaller in the United Kingdom/United States case at .013 (.006) for wage-bill shares and .013 (.007) for employment shares (standard errors are in parentheses). In Sweden they are .022 (.013) and .025 (.007), respectively. And they are higher in Denmark/J apan at .048 (.012) and $.046(.012)$. The appropriate $\chi^{2}(2)$ test statistics of simplifying to a model with identical $R \& D$ effects in all countries can be rejected (with test statistics of 6.38 for wage bill shares and 6.26 for employment shares, 5 percent critical value $=5.99$ ).

14. Our purpose in this paper is to focus on cross-country correlations between skill upgrading and $R \& D$ using data defined at the same level of disaggregation across countries. This insistence on cross-country consistency may well mean that we are making things more difficult in terms of identifying evidence of SBTC. That this may be true is borne out by the fact that our correlations for the United States seem, if anything, to be smaller than those based on much more disaggregated data as reported in Berman, Bound, and Griliches [1994] and Autor, Katz, and Krueger [1998]. However, a clear comparison is rather hard here for a number of reasons (e.g., those papers define R\&D intensity as (R\&D/sales), and we use (R\&D/value added), and they cover different time periods). 
The pattern that emerges is therefore an intriguing one. There is a significant association between skill upgrading and $R \& D$ intensity in all countries. Put more bluntly, technology matters everywhere. However, in the countries that have experienced bigger increases in wage inequality and faster skill upgrading, a unit increase in $R \& D$ intensity is associated with a significantly lower shift in skill structure. On the other hand, in countries where wage inequality has remained stable and smaller shifts in skill structure have occurred, our measure of technology can account for a larger fraction of the observed change.

\section{Further Considerations}

There are many issues and extensions that follow from the nature of the specifications reported in the previous section. In this section we investigate some of these where we probe further the robustness of the key findings.

\section{A. Computer Usage}

A common alternative to $R \& D$-based technology measures is some index of computer use across industries. For the United States and the United Kingdom, we calculated the proportion of workers in our industries who were using computers at work in the mid-1980s. ${ }^{15}$ This is essentially the same variable used by Autor, Katz, and Krueger [1998] and has the advantage of being a direct measure of the diffusion of a new technol ogy. ${ }^{16}$ The correlation of computer use with R\&D intensity was high (.78 in the United Kingdom and .83 in the United States), and the industrybased cross-country correlation is also high at .79. Rerunning the cost-share-based models in Table IV, replacing the R\&D intensity variable with the computer usage variable gave similar results, uncovering an important complementarity between skill upgrading and this alternative measure of technology. ${ }^{16}$

15. Data come from the Current Population Survey in the United States and from the British Social Attitudes Survey in the United Kingdom.

16. The estimated coefficients (and associated standard errors) were as follows: United Kingdom-wage bill shares .010 (.004) [one year changes], .006 (.004) [four-year changes]; employment shares .011 (.003) [one year changes], .008 (.004) [four-year changes]; United States- wage-bill shares .011 (.005) [one-year changes], .011 (.005) [four year changes]; employment shares .011 (.004) [one-year changes], .010 (.004) [four-year changes]. 


\section{B. Foreign Competition}

The main alternative story to technology-driven changes is that increased foreign competition has damaged the position of less skilled workers [Freeman 1995; Wood 1994]. We have constructed two measures of changes in import competition for our industry panels (changes in the ratio of total imports to value added and in the ratio of imports from non-OECD countries to value added) and examined the extent to which one sees a cross-country correlation pattern by industry. At first glance, the cross-country patterns of increases in import competition look like they may be broadly supportive of the trade view. Like skill upgrading (and $R \& D$ intensity) bigger changes in import competition from 1973-1989 seem to be clustered in much the same industries over time. For the 21 pairwise comparisons of crosscountry correlations that we can carry out with our data, all were positive for both import variables, 7 were significant (at the 5 percent level) for the total imports variable, and 17 were significant for the non-OECD imports variable. So it appears to be the case that faster increases in import competition, especially from non-OECD countries, were concentrated in similar industries over time (it is also true that higher levels of import intensity are concentrated in the same industries).

Taking the next step to see whether these import variables were correlated with the extent of skill upgrading, we then augmented our cost-share model with these extra variables. On some readings of the "trade hypothesis," one would expect the industries with faster rising import intensities to be reducing the proportion of their unskilled workers at a faster rate. Table $V$ tests this hypothesis. To keep things clear, only non-CRS specifications in the four-year change models are reported (the same pattern of results is upheld in one-year models and if constant returns are imposed). Four specifications are reported for each country, the first two rows including the imports variables in levels, the final two incorporating the variable in changes. In no case was the coefficient on the imports variable correctly signed and significantly different from zero. In many cases the imports coefficient attracted a perverse negative sign. While rising import competition is concentrated in similar industries across countries over time, and the same is true of skill upgrading, they do not appear to be the same ones.

What is more, it is important to note that the $R \& D$ coefficient remains very robust to the inclusion of the trade varia- 
bles. ${ }^{17}$ Although this robustness is reassuring, a cautionary note must be added. Supporters of the trade-based explanation of changing skill structures emphasize that the effects of trade area general equilibrium phenomenon. Thus, one may not necessarily expect there to be a positive correlation between within-industry shifts in import intensity and skill structure. In related work (Desjonqueres, Machin, and Van Reenen [1998]) we show that even if one examines disaggregated nontraded sectors it is possible to uncover evidence of skill upgrading-a fact which is hard to reconcile with a puretrade-based explanation. ${ }^{18}$

\section{Potential Endogeneity of $R \& D$}

In common with most of the existing literature, we have so far taken technical change to be exogenous. This may be a problematic assumption. If firms expect skills to be growing at a particularly fast ratein their sector, it may beless costly for them to adopt new technologies and perform more $R \& D$. Thus, the technologyskills correlation would be due to endogenous technological advance (as is suggested by some endogenous growth theories). To the extent that $R \& D$ only responds sl owly to shocks to skills (e.g., because of high adjustment costs), this may be less of a severe problem (in econometric terms it is not strictly exogenous, but predetermined). ${ }^{19}$

It is notoriously hard to find convincing instruments for technology. Here we investigate the possibility of using government-funded business enterprise R\&D. If government behavior

17. Work based on U. S. data (e.g., Autor, Katz, and Krueger [1998] and Feenstra and Hanson [1996]) has tended to find stronger effects of changes in export intensity or outsourcing (defined as imported inputs/total nonenergy material purchases). We have experimented with specifications that include changes in exports/value added but find little change in the nature of the results, in particular the estimated coefficient on industrial $R \& D$ intensity remains essentially unchanged (we do not have cross-country industry data on outsourcing to examine the F eenstra-Hanson hypothesis). It is al so not obvious how one should read coefficients on changes in export intensity as the link between rising export propensities and the extent of competition is not clear.

18. This work also shows that (i) the "prize puzzle" of a weak correlation between industry skill intensity and price changes exists outside the United States; and (ii) patterns of skill change in developing countries are largely inconsistent with simple (Heckscher-Ohlin type) trade models. Of course, the existence of within-sector skill upgrading in nontraded sectors does not rule out the idea that trade could be a contributing factor, merely that it cannot be the only important source of increased labor demand for the more-skilled.

19. A second reason for instrumenting could be measurement error associated with the problem of "double counting." This is because few production workers are involved in $R \& D$. However, since the number of $R \& D$ workers in an industry is small, this is likely to be a second-order problem. 
can be taken as exogenous, then although government-funded $R \& D$ is likely to affect the amount of $R \& D$ conducted in the industry, it will be uncorrelated with the error term in the cost-share equation. Government-funded R\&D varies across industries and over time, and we use this independent variation in constructing instrumental variable (IV) results. The first two columns of Table VI contain these results. The first row for each country reports the coefficient and standard error on the government $R \& D$ variable in the first-stage reduced-form " $R \& D$ equation." As can be seen, the instrument is highly significant in all cases. Next consider the second and third rows which present estimates of the IV R\&D coefficient in the cost-share equations (with and without imposing constant returns). Compared with the models where $R \& D$ is assumed exogenous, the IV coefficient estimates, although estimated with less precision, are remarkably close. In some countries (such as J apan) the coefficient actually rises in magnitude, although the main pattern is no change or a small fall. In no case are the coefficients significantly different from the case where $R \& D$ is assumed exogenous, and the overall thrust of results remains very robust.

Issues to do with the timing of the $R \& D$ variable are also linked to endogeneity questions. We have also considered models where initial period (1973) $R \& D$ intensity is entered into the skill-upgrading equations. Specifications contained in the final column of Table VI show that the correlation between skill upgrading and $R \& D$ still holds when initial $R \& D$ intensity is used. In the same vein, when pooled wage-bill-share models were estimated exactly, the same story emerged: one can reject the null hypothesis of a common $R \& D$ coefficient across countries in favor of a model that groups the $R \& D$ coefficient for Denmark and J apan (coefficient $=.055$, standard error $=.012$ ), Sweden (.040, $.014)$, and the United Kingdom and the United States $(.012, .007)$, the appropriate $\chi^{2}(2)$ statistic being 10.59 .

\section{Spillovers}

A further possible criticism of using own $R \& D$ as a measure of technology is that it ignores any international spillovers arising from the public good nature of knowledge. Constructing a spillover pool is by no means easy, ${ }^{20}$ but one simple method is to calculate the amount of worldwide $R \& D$ for each industry using

20. See Coe and Helpman [1995] for a recent attempt to use trade flows to construct an international spillover measure. 
TABLE VI

Potential Endogeneity of $(R \& D / Y)$

\begin{tabular}{|c|c|c|c|c|}
\hline & & \multicolumn{3}{|c|}{$\begin{array}{l}\text { Changes in nonproduction wage-bill shares } \\
\text { (four-year changes, annualized) }\end{array}$} \\
\hline & & $\begin{array}{l}\text { Coefficient (se) } \\
\text { on }(R \& D / Y), \\
\text { IV estimates }\end{array}$ & $\begin{array}{c}\text { Coefficient (se) } \\
\text { on (Government } \\
\text { R\&D/Y) }\end{array}$ & $\begin{array}{l}\text { Coefficient (se) } \\
\text { on initial } \\
\text { period (R\&D/Y) }\end{array}$ \\
\hline \multirow[t]{4}{*}{ Denmark } & $R \& D$ equation & & 8.625 (1.271) & \\
\hline & $\begin{array}{l}\text { Wage-bill-share } \\
\text { equation, CRS }\end{array}$ & $.016(.012)$ & & $.037(.016)$ \\
\hline & $\begin{array}{l}\text { Wage-bill-share } \\
\text { equation, relax }\end{array}$ & & & \\
\hline & CRS & $.022(.017)$ & & $.055(.011)$ \\
\hline \multirow[t]{4}{*}{ J apan } & $R \& D$ equation & & 30.193 (11.951) & \\
\hline & $\begin{array}{l}\text { Wage-bill-share } \\
\text { equation, CRS }\end{array}$ & $.059(.029)$ & & $.052(.012)$ \\
\hline & $\begin{array}{l}\text { Wage-bill-share } \\
\text { equation, relax }\end{array}$ & & & \\
\hline & CRS & $.070(.030)$ & & $.055(.018)$ \\
\hline \multirow{4}{*}{ Sweden } & $R \& D$ equation & & $11.263(2.427)$ & \\
\hline & $\begin{array}{l}\text { Wage-bill-share } \\
\text { equation, CRS }\end{array}$ & $.031(.028)$ & & $.063(.018)$ \\
\hline & $\begin{array}{l}\text { Wage-bill-share } \\
\text { equation, relax }\end{array}$ & & & \\
\hline & CRS & $.030(.024)$ & & $.037(.015)$ \\
\hline \multirow[t]{4}{*}{ U.K. } & $R \& D$ equation & & $2.218(.217)$ & \\
\hline & $\begin{array}{l}\text { Wage-bill-share } \\
\text { equation, CRS }\end{array}$ & $.024(.010)$ & & $.032(.016)$ \\
\hline & $\begin{array}{l}\text { Wage-bill-share } \\
\text { equation, relax }\end{array}$ & & & \\
\hline & CRS & $.009(.010)$ & & $.017(.013)$ \\
\hline \multirow[t]{4}{*}{ U.S. } & $R \& D$ equation & & $1.964(.206)$ & \\
\hline & $\begin{array}{l}\text { Wage-bill-share } \\
\text { equation, CRS }\end{array}$ & $.021(.010)$ & & $.019(.007)$ \\
\hline & $\begin{array}{l}\text { Wage-bill-share } \\
\text { equation, relax }\end{array}$ & & & \\
\hline & CRS & $.013(.009)$ & & $.009(.008)$ \\
\hline
\end{tabular}

Government funded R\&D is estimated from the OFBERD data set. I nitial $(R \& D / Y)$ is dated 1973 (except for J apan which is 1974). R\&D instrumentation equation and wage-bill-share equations include the same variables as the CRS and non-CRS specifications in Table IV. All four-year changes are annualized, and all regressions include a full set of time dummies. Regressions are weighted by industry size (wage bill share). Estimation is by (IV) GLS/random effects where theindustry errors areallowed to be correlated for industries over time. Heteroskedasticity-consistent standard errors are in parentheses.

the entire STAN database (essentially all OECD R\&D). After subtracting own $R \& D$ and normalizing on world value added in the industry (net of own value added), the spillover variable was entered al ongsidethe own $R \& D$ variable. One should bear in mind 
that, as with the cross-country $R \& D$ correlations considered earlier (in Table II), own R\&D and the spillover term are highly correlated so identification of separate effects is asking rather a lot. Nevertheless, the broad pattern that emerged is of some interest. In the United Kingdom and the United States the coefficient on the spillover variable was small and statistically insignificant. But in the other countries it was estimated to be positive and statistically significant, and the coefficient on own $R \& D$ was driven to insignificance. ${ }^{21}$ Taken as a whole, the results suggest spillovers to be potentially more important in the smaller Scandinavian economies and J apan than in the United States and the United Kingdom.

\section{ConClusions}

This paper has reported evidence related to the question of whether the observed intertemporal shifts in the skill structure of international labor markets can be accounted for by skill-biased technological change. Using a newly constructed industry level database, we have contrasted the experience of seven industrialized nations: Denmark, France, Germany, J apan, Sweden, the United Kingdom, and the United States. Our countries provide an interesting comparison because, over the time period considered, there was skill upgrading in all cases, but there were also dramatic changes in the wage structure of the United Kingdom and the United States, with relative stability elsewhere. If a similar common technology shock hit the developed world, then the contrast between these countries should give some insight into the relative importance of different explanations for changes in the skill structure.

Our analysis leads to the conclusion that there exist important skill-technology complementarities across all countries. This finding was robust to experiments using different measures of

21. For the non-CRS case, in four-year change wage-bill share models, the following coefficients (standard errors) were obtained: Denmark, (R\&D/Y) .001 (.006), spillover .040 (.006); J apan, (R\&D/Y ).008 (.015), spillover .036 (.015); Sweden, (R\&D/Y) -.066 (.050), spillover .097 (.050); the United Kingdom, $(R \& D / Y) .018(.019)$, spillover - $.006(.021)$; the United States, $(R \& D / Y) .024(.015)$, spillover $-.015(.024)$. The same pattern of results emerged in the CRS case (insignificant own R\&D effects with positive significant spillovers in Denmark, $J$ apan, and Sweden), except in the United Kingdom and, the United States where the positive own R\&D effect was larger and more precisely determined (at .042 (.014) and .030 (.016), respectively). The coefficient on the spillover variable remained negative and insignificant in both these countries.- 
skill, introducing trade variables, and instrumenting R\&D. Thus, it is likely that the move toward higher $R \& D$ intensities and increased computer usage (see also Autor, Katz, and Krueger [1998]) are factors that have contributed to reducing the relative demand for the unskilled.

To what extent can technical change account for changes in the structure of labor markets in industrialized nations? The results presented here can be interpreted as offering evidencethat technol ogy has been very important. It seems that $R \& D$ intensity pushes up the demand for skills and $R \& D$ intensity was higher in all countries in the 1980s than in the 1970s. There are several important caveats to be borne in mind, however. First, a full analysis needs to take into account the differential growth in the supply of skilled workers. Although this has been increasing across all countries, the rate of acceleration has been different, and equilibrium skill differentials will in part reflect these differences. Second, although R\&D intensity is relatively high in the United Kingdom and the U nited States, the rate of growth has been slower, and the estimated coefficients on the $R \& D$ variable in skill upgrading equations appear to be somewhat lower in the United Kingdom and the United States than in other countries. Taken together with the fact that the skill structures were changing most rapidly in these two countries, it seems likely that there are other factors in addition to technology that have contributed to the declining labor market position of unskilled workers.

The additional factor that has received most attention to date is rising international trade, and it is natural that much current research focuses on this. However, we remain rather skeptical about the direct role of trade (i.e., through Heckscher-Ohlin type routes). A more fruitful path may well be to better integrate arguments to do with the declining role of labor market institutions into generating a fuller understanding of what lies behind the observed changes in skill structure. The ability of institutions to set wages, affect training, and reduce the power of firms to lay off unskilled workers is likely to impact on relative wages and employment. The cross-country pattern of results reported in this paper, coupled with the dramatic weakening of these institutions in the United Kingdom and the United States in the 1980s and their relative persistence in Europe, suggests that this could well be an important factor-in addition to technical change-in 
explaining the changing skill structure of the countries examined here.

\section{Data Appendix}

The data used in this paper come from a variety of industry and individual level data sources. The main aim is to consider the relationship between skill upgrading and technology across countries in the same industries. This requires the matching of data from a number of sources and at different levels of industry disaggregation. We focus on the manufacturing sectors of seven countries (Denmark, France, Germany, J apan, Sweden, theU nited Kingdom, and the United States). From our matching of the relevant data sources described below, aggregate manufacturing can be broken down into sixteen industries at (broadly) the two-digit level. All the industry-based work in the paper that requires the use of $R \& D$ data focuses on fifteen industries only, dropping the transport goods sector because of problems with the $R \& D$ data for this sector (see bel ow).

The fifteen sectors considered were chemicals (including drugs); el ectrical, radio, TV, and communications; food, beverages, and tobacco; iron and steel; metal products; nonelectrical machinery (including computers); nonferrous metals; nonmetallic mineral products; other manufacturing; paper products and printing; coal and petroleum products; professional goods; rubber and plastic goods; textiles, apparel, and leather; wood products and furniture.

The data sources used to set up the panel data for these industries over time were the following.

\section{OECD STAN Database}

STAN is a data set constructed in a long-term project by the OECD who work together with the Central Statistical Offices of OECD countries to compile consistent industry-level data over time from the early 1970s. All data are originally in unscaled national currencies. They can be converted to dollars using annual average values of the exchange rate. Industrial classifications are detailed in OECD [1997c]. There are three OECD databases which can be merged consistently in the STAN series.

(a) Business Enterprise R\&D (ANBERD). This contains data on $R \& D$ conducted by industry regardless of funding source and is available from 1973 for the following countries: the United 
Kingdom, France, Canada, Germany, Italy, J apan, the United States, Australia, Denmark, Finland, the Netherlands, and Sweden for 22 disaggregated industries (see OECD [1997b]). These figures have been adjusted to ensure comparability and so differ from the official figures for the individual countries. State-owned industries' R\&D are included in all countries. As noted above, there appeared to be problems in constructing the R\&D figure for the transport industries (this is related to the large amount of military/government expenditure, especially in the United Kingdom and the United States, erratic figures for the aerospace industries, and the fact that $R \& D$ data were missing for some subsectors of the transport industry). Consequently, this industry was dropped.

(b) OECD, DSTI(STAN/I ndustrial Database) contains data on investment, value added, and exchange rates. From the investment data capital stock measures were constructed using the perpetual inventory method and a depreciation rate of 8.4 percent (a weighted average of the depreciation rates for plant and machinery and buildings used in OECD [1991]). I nitial year stocks assumed a presample growth rate of 5 percent. Data are National Accounts compatible where available, otherwise OECD estimates are made.

(c) Import and export data are from OECD's Compatible Trade and Production database (COMTAP). Figures are consistent across countries but may not be strictly comparable to trade flows published in other sources.

\section{United Nations General Industrial Statistics Database (UNISD)}

Data for wage bills and employment for production/nonproduction workers were obtained for Denmark, Sweden, the United Kingdom, and the United States from the Statistical Division of the United Nations from 1970 onward (up to 1991 in some countries). The key data are reported in terms of "employees" and "operatives," the latter of which are taken to be production workers, and nonproduction workers are the rest. More recent data are not available as the UN stopped collecting data disaggregated in this way after responsibility for the UNISD was moved from New York to Vienna. The UNISD database contains similar information (in particular on capital formation) to the STAN database, but differs from it in that the STAN database is derived from sample information which is then calibrated by national 
accounts numbers, whereas the UN figures report the survey results (e.g., from the United States Annual Survey of Manufactures or the United Kingdom Census of Production). After cleaning the data, consistently defined data on nonproduction shares were available for 1973-1989 (Denmark) and 1970-1985 (Sweden), 1970-1990 (United Kingdom), and 1970-1991 (United States).

\section{OECD Bilateral TradeDatabase}

Data on imports from non-OECD countries were matched in from the OECD Bilateral Trade Database.

\section{OECD OFBERD}

OFBERD ("Official"BERD) is an unpublished data set compatible with STAN/ANBERD which is compiled by the OECD. In OFBERD R\&D performed by the business sector is broken down into sources of finance. Some data points were imputed using linear interpolation due to missing observations. We distinguish between $R \& D$ funded by government and by the private sector (domestic or foreign). Government-funded $R \& D$ is primarily direct grants and contracts.

\section{Individual-Level Data Sources}

Individual-level data sources were aggregated to industry level for the following.

(a) Nonproduction wage-bill and employment shares in J apan (Source: J apanese Wage Survey) and nonproduction employment shares in Germany (Source: Mikrozensus). As data were not available for all years, some values were imputed.

(b) High education employment shares (defined as the share of the workforce with a college degree) for France (1977-1991, Source: Enquete Emploi), Germany (1977-1991, Source: Mikrozensus), J apan (1977-1990, Source: J apanese Wage Survey), Sweden (1986 and 1993, provided by Par Hansson, data from ARSYS Regional Statistics Database, Statistics Sweden), the United Kingdom (1979-1991, Source: Labour Force Survey), and the United States (1977-1991, Source: Current Population Survey). In some cases data were not available annually so in these cases data were interpolated between years, and in Sweden only two years were available (1986 and 1993). 


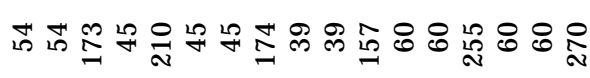

|

寽器

吉吉

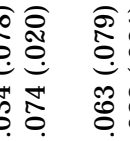

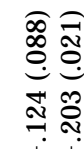

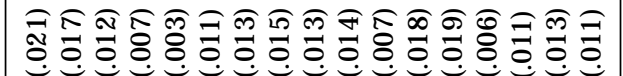

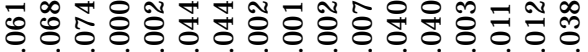

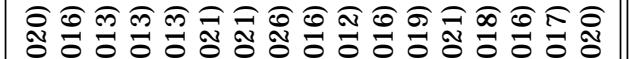

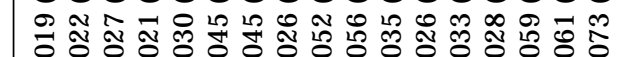

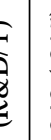

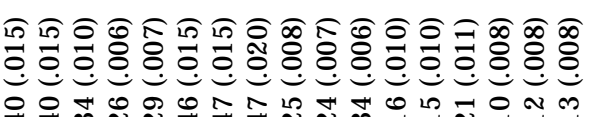

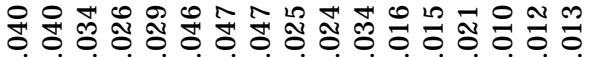

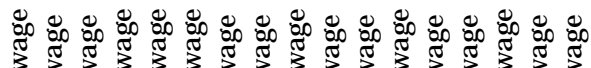

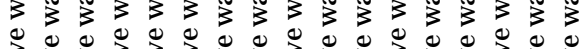

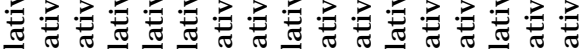

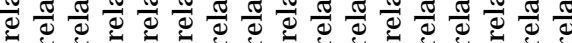

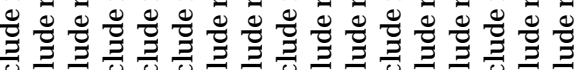

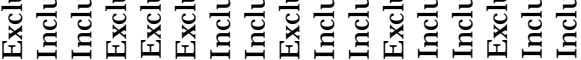

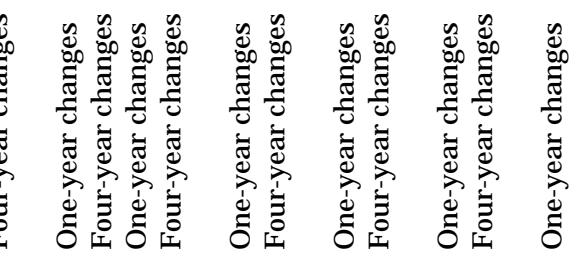

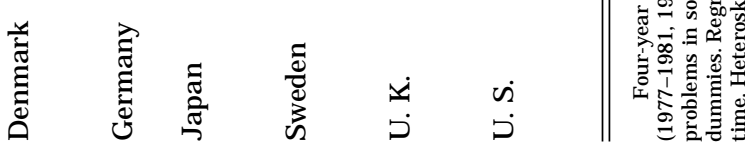


Department of Economics, University College London and Centre for EcoNomic Performance, London SChOOL OF ECONOMICS DEPARTMENT OF ECONOMICS, UNIVERSITY COLLEGE LONDON, UNIVERSITY OF CALIFORNIA AT BERKELEY, AND INSTITUTE FOR FISCAL STUdIES

\section{References}

Autor, David, Lawrence Katz, and Alan Krueger, "Computing Inequality: Have Computers Changed the Labor Market," QuarterlyJ ournal of E conomics, CXIII (1998), 1169-1213.

Berman, Eli, J ohn Bound, and Zvi Griliches, "Changes in the Demand for Skilled Labor within U. S. Manufacturing Industries," Quarterly J ournal of EconomiCS, CIX (1994), 367-398.

Berman, Eli, J ohn Bound, and Stephen Machin, "Implications of Skill-Biased Technological Change: International Evidence," QuarterlyJ ournal of E conomics, CXIII (1998), 1245-1279.

Bound, J ohn, and George J ohnson, "Changes in the Structure of Wages in the 1980s: An Evaluation of Alternative Explanations," American Economic Review, LXXXII (1992), 371-392.

Card, David, Francis Kramarz, and Thomas Lemieux, "Changes in the Relative Structure of Wages and Employment: A Comparison of the United States, Canada, and France,"NBER Working Paper N o. 5487, 1996.

Coe, David, and Elhanan Helpman, "International R\&D Spillovers," European Economic Review, XLV (1995), 859-887.

Desjonqueres, Thibaut, Stephen Machin, and J ohn Van Reenen, "Another Nail in the Coffin? Or Can the Trade-Based'Explanation of Changing Skill Structure BeResurrected?" Centrefor E conomic Performance, London School of Economics, mimeo, 1998.

Feenstra, Robert, and Gordon Hanson, "Globalization, Outsourcing and Wage Inequality," American Economic Review Papers and Proceedings, LXXXVI (1996), 240-245.

Freeman, Richard, "Are Your Wages Set in Beijing?" J ournal of Economic Perspectives, IX (1995), 15-32.

Griliches, Zvi, Bronwyn Hall, and Ariel Pakes, "R\&D, Patents and Market Value Revisited: Is There a Second (Technological Opportunity) F actor?" E conomics of I nnovation and New Technology, I (1991), 183-202.

Hall, Bronwyn, and J acques Mairesse, "Exploring the Relationship between R\&D and Productivity in French Manufacturing Firms,"] ournal of Econometrics, CXV (1995), 263-293.

Haskel, J onathan, and Mathew Slaughter, "The Sector Bias of Skill-Biased Technological Change: Theory and International Evidence," Queen Mary and Westfield College, mimeo, 1998.

J ohnson, George, "Changes in Earnings I nequality: The Role of Demand Shifts," J ournal of Economic Perspectives, XI (1997), 41-54.

Machin, Stephen, and J ohn Van Reenen "Technology and Changes in Skill Structure: Evidence from Seven Countries," Labour Market Consequences of Technical and Structural Change Discussion Paper No. 24, 1997.

OECD, "Taxing Profits in a Global E conomy; Domestic and I nternational I ssues" (Paris: OECD, 1991).

OECD, "Research and Development Expenditure in Industry 1973-1995" (Paris: OÉCD, 1997a).

OECD, "ANBERD, Analytic Business Expenditure on R\&D” (Paris: OECD, 1997b).

OECD, “STAN, Standardized I ndustrial Database” (Paris: OECD, 1997c).

Van Reenen, J ohn, "Why Has Britain had Slower R\&D Growth?" Research Policy, XXVI (1997), 493-502.

Wood, Adrian, North-South Trade, Employment and I nequality (Oxford: Clarendon Press, 1994). 